\title{
An Innovative Use of Eco-management Scheme: Some New Applications
}

\author{
Andrea Rocchi ${ }^{1, *}$, Martucci Olimpia ${ }^{2}$ \\ ${ }^{1}$ Department of Communication and Social Research, Sapienza University of Rome, Italy \\ ${ }^{2}$ Department of Management, University of Rome 3, Italy
}

Copyright $\bigcirc 2018$ by authors, all rights reserved. Authors agree that this article remains permanently open access under the terms of the Creative Commons Attribution License 4.0 International License

\begin{abstract}
Eco-management scheme (EMAS), since its first application, has evolved over time. In its last review, it promotes the best environmental management practices through the development of sectoral reference documents that have to be taken into consideration by the "EMAS-registered organizations" in assessing their environmental performance. Many organizations and companies have a wide margin to improve their environmental performance. With the aim to improve their eco-efficiency and thus its reputation and the sustainability of their business, many companies want to lower their impact on the environment. To help organizations achieve this goal, the CCR identifies, evaluates and documents best environmental management practices (BEMPs) for the different sectors, in collaboration with stakeholders. The results of this work are some sectoral reference documents (SRD) on best practices in environmental management. This activity is part of the European Commission's work to implement the system of EU management and Audit Scheme (EMAS), a voluntary framework for enterprises and other organizations to evaluate, report and improve their environmental performance. In this context, the EU decided in 2009 to promote best environmental management practices through the development of sectoral reference documents.
\end{abstract}

Keywords EMAS, Environmental, Best Practice

\section{Introduction}

The EU has integrated sustainable development policies through the European Union Strategy for Sustainable Development (SDS), as well as the action plan (Rocchi A, Amodeo G.U, Jirillo R., 2007 [10]) for environmental technologies prioritizing sustainable consumption and production (SCP), also highlighted in Europe as a strategy for 2020. SCP is in this context, aimed at promoting economic growth and social cohesion without compromising the quality of the environment. A key feature of this strategy is to identify best practices in the environmental field (BEMPs) within the processes and areas under investigation by Eco-management scheme. JRC $^{1}$ (Joint Research Centre) sustains this objective through the analysis of the relationship between technological change, scientific developments, the environment, the economy and political approaches. For this reason, it produces technical and economic analyses of technological options and socio-economic analyses based on analytical modelling.

Since its inception, Emas (Bianchi G., 2000, [4]) has always had an increase in interest and application, except in the last few years. An important fact concerns the leading countries, where the numbers of registrations in Germany have actually declined gradually since 2005 , whereas for all other countries registrations remained steady or increased until 2012. In contrast, Spain and Italy experienced a steady growth year by year, with Italy (Thione L., 2014 [12]) starting at roughly the same level as Austria in 2005 and increasing to over 1000 organizations by 2010. After increasing up until 2012, both Spain and Italy experienced a significant drop in registrations in 2013. This downward trend stopped in 2014 for Spain and Germany.

\footnotetext{
1 Joint Research Centre (JRC) is a Directorate-General Joint Research Centre (DG-JRC) which has seven research institutes located in five EU Member States (Belgium, Germany, Italy, The Netherlands and Spain). It provides scientific and technical support for the design, development, implementation and monitoring of European Union policies. Unlike European universities, it is directly funded by the European Union (it is a service of the European Commission), in order to ensure the independence of research activities from private interests or national policy - an essential condition for pursuing its international mission.

The JRC has a coordination and research role in numerous community networks of national research institutions, universities, advanced industrial member states of the European Union, in addition to conducting a wide range of independent research that makes use of the best European scientists' skills, working directly in the centre or performing periodical research. Complex studies and experiments on behalf of European institutions are conducted in its laboratories. JRC collaborates with non-European organizations and global networks in the scientific and regulatory fields.
} 


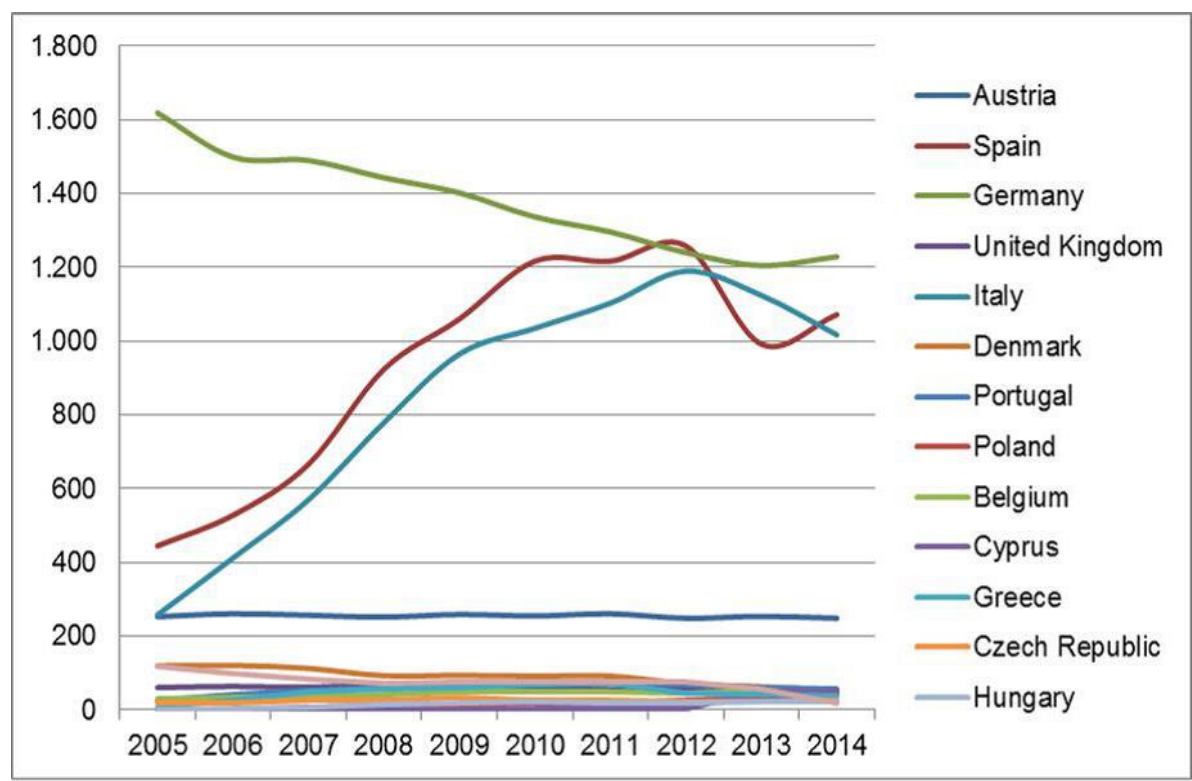

Figure 1. Number of EMAS-registered organizations and sites per Member State (April 2014)

Anyway the situation described in the figure (fig. 1) highlights the fact that during the European economic crisis the certifications from 2011 have strongly decreased, demonstrating the lack of environmental propensity of companies in times of economic hardship.

\section{Sustainable Production: Best Available Techniques}

Industrial production processes account for a considerable share of overall pollution in Europe. EU has a common set of rules for the control of industrial plants, described in the Industrial Emissions Directive 2010/75/EU (IED). JRC manages the European Integrated Pollution Prevention Control (IPPC) Bureau that produces reference documents on best available techniques, used by the competent authorities in the EU Member States for issuing operating permits.

Product consumption and production is responsible for a large number of environmental problems, ranging from air, water and soil pollution to an increase in resource consumption as well as negative impacts on health. The European Commission has addressed this problem for some time through a series of policy instruments which are subsumed under the policies of the Sustainable Consumption and Production Plan of Action COM (2008) 397. JRC manages the European Office created to support this work through the ability to scientifically assess the environmental performance of a wide range of product groups, and through operational management of the policies' implementation process for the promotion of Ecolabel Regulation EC 66/2010, the Green Public Procurement Communication COM (2008) 400, the ErP 125/2009/EC (Eco-design requirements for energy-related products) and Energy labelling directive 2010/30/EU.

\section{Best Environmental Management Practices (BEMPs)}

Many organizations and companies have significant possibilities and potential to improve their environmental performance. For reasons ranging from eco-efficiency, reputation and concerns about the sustainability of their business (Rocchi A. Jirillo R., 2010 [11]), many of them therefore intend to reduce their impact on the environment.

To help organizations achieve this goal, the JRC identifies, evaluates and produces the documents and necessary guidelines to promote best environmental management practices (BEMPs) for different sectors while in close cooperation with stakeholders. To do this, the JRC follows the so-called leader approach, namely studying the techniques, measures or actions which are implemented by the most advanced sector organizations in terms of environmental performance in each of the various areas, such as energy efficiency, resource efficiency, emissions, but also Supply Chain Management. The results of this work are sectoral reference documents (SRD) on the best environmental management practices.

This activity is part of the European Commission's work towards the implementation of the Eco-Management and Audit Scheme of the EU (EMAS), a voluntary framework for companies and other organizations to evaluate, report and improve their environmental performance (Battaglia M., Daddi, T., 2006, [3]). Within this framework, in 2009 the EU decided to promote best environmental management practices through the development of sectoral reference documents.

\section{Priority Areas}

Sectoral reference documents on best environmental 
management practices are being studied and will be developed for a list of priority sectors. The first sectors being considered are: retail trade, tourism, construction, public administration, Agriculture - Crop and Animal Production and Food and beverage production. The European Commission has set an indicative list of priority sectors for which reference sectoral documents should be developed. The prioritized sectors are as follows: Retail trade, Tourism, Construction, Public administration, Agriculture - Crop and Animal production, Food and beverage production, Automobile manufacturing, Electrical and electronic equipment manufacturing, Waste management, Metal products manufacturing, except machinery and equipment, Telecommunications.

\section{BEMP Related to the Tourism Sector}

Tourism is an important economic sector in Europe, in the EU alone there are 1.7 million companies classified as hotels and restaurants, employing more than 9 million people and generating an annual turnover of 430 billion euro. Europe is the largest tourist region in the world, which hosts $53 \%$ of international tourist arrivals. Five European countries enter the top ten in the world for international arrivals: France, Spain, Italy, the UK and Germany. The average long-term growth rate of the European tourism sector is $2.8 \%$. Tourists have a large environmental impact compared to residents: long travels and especially elevated environmental footprints come from their focusing often on "hot spots", where they can create local environmental pressures through the demand for development, water and energy, and mass production of waste. The consumption of resources per guest is high in accommodations and establishments, food and beverages, and often the eco-efficiency of such structures is quite variable, indicating a high potential for improvement through the dissemination of best practices. Through a targeted and conscious choice, "green" facilities management and a change in services offered, tourist business management can produce a positive environmental influence on a broader scope, and well-managed tourism is able to generate income from natural resources in a truly sustainable way. The main direct and indirect environmental aspects of the sector are described in the following input / output scheme:

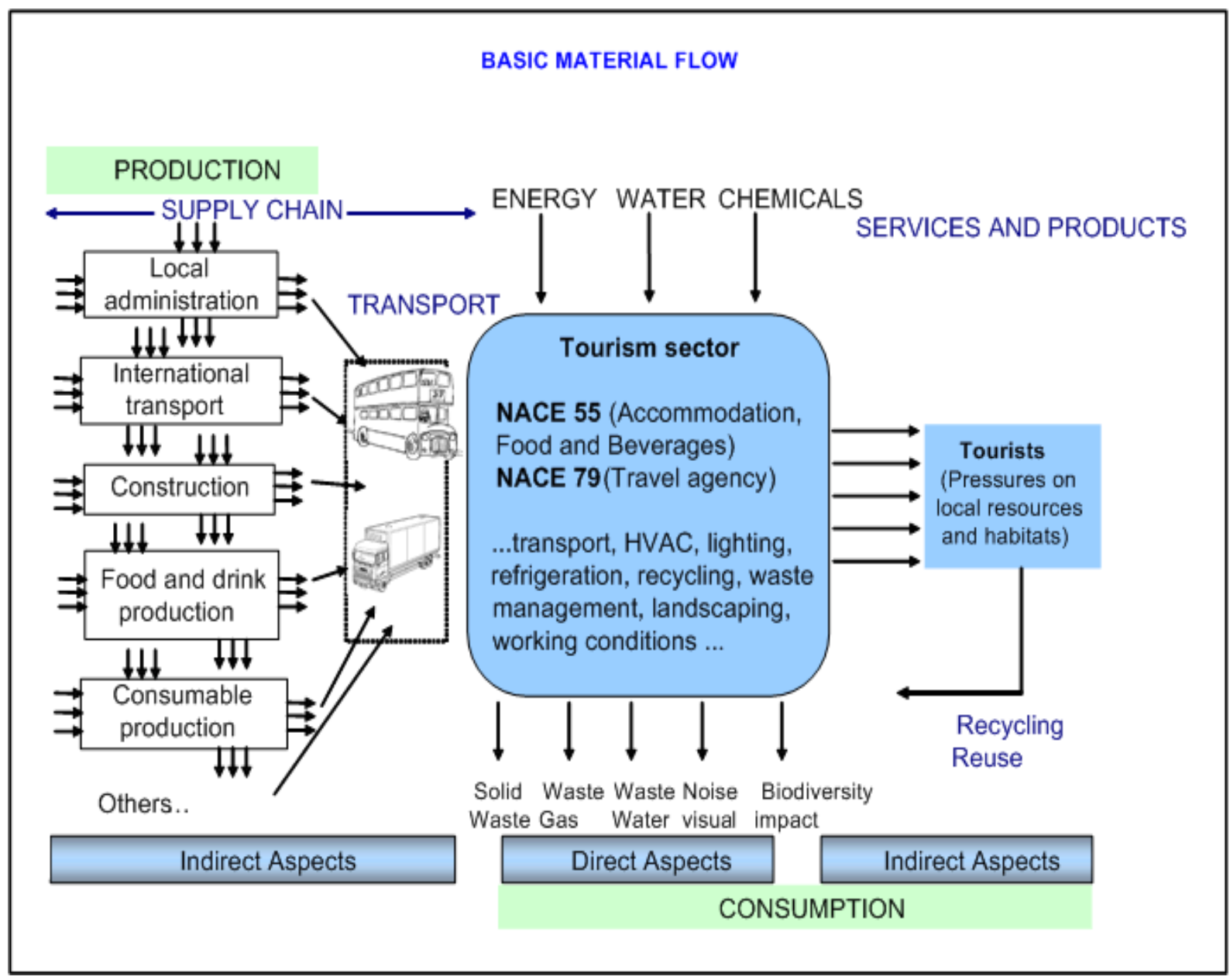

Figure 2. BEMP scheme 
Best Environmental Management Practices (BEMPs) are the best practices identified at the process level, targeting key stakeholders to address the most significant environmental aspects:

- $\quad$ BEMPs for destination management. These include development planning and conservation measures.

- BEMPs for tour operators and travel agencies. These include cooperation with destination managers to improve destinations' environmental conditions.

- BEMPs to minimize energy use in accommodations.

- BEMPs to minimize water consumption in tourist accommodations.

- BEMPs to minimize and manage waste in accommodations.

- $\quad$ BEMPs for food and drink suppliers. These include the procurement and efficient management of food products, optimized waste management, efficient washing and cleaning processes and highly efficient cooking processes.

- BEMPs for campsites. These include the site's environmentally friendly management, efficient hygienic services, the use of renewable energy sources, and the provision of waste management services.

For each BEMP, key indicators of environmental performance have also been identified (for measuring the environmental performance in each area), and benchmarks of excellence (an indication of the level of environmental performance achieved by the best players in the industry).

\section{Conclusions}

In light of the above and of the environmental improvements implemented by the Commission and the various European organizations towards a process of implementation of best practices and performances in the environmental field, we can see that EMAS has entered a phase of refinement and finalization of processes and objectives. All this is taking place in a clear and straightforward path, even if long and complex, giving more body and substance to a scheme with voluntary membership, which is precisely EMAS, but that has long ago become a full part of the technical rules in the environmental field.

\section{REFERENCES}

[1] ANPA (Agenzia Nazionale per la Protezione dell'Ambiente), 1999, Linee guida per l'applicazione del Regolamento CEE n. 1836/93 (EMAS) e della Norma ISO 14001 da parte della piccola e media impresa, Roma;

[2] ANPA (Agenzia Nazionale per la Protezione dell'Ambiente),1999, Il Regolamento 1836/93 (EMAS), Stato di attuazione in Europa e in Italia, Roma;

[3] Battaglia M., Daddi, T., 2006, Tre possibili declinazioni del Regolamento EMAS, Pisa;

[4] Bianchi, G., 2000, Ambiente e Sviluppo, Sviluppi di EMAS in Italia e nella UE, n. 4 luglio - agosto, pp. 36-39.

[5] Biserni S., 2008, Indagine conoscitiva sullo stato di attuazione di EMAS in Italia, Tesi finale di stage c/o ISPRA, 2008

[6] Gamboni, M., 2003, Il logo EMAS, Rifiuti - bollettino di informazione normativa, n. 94, marzo 2003;

[7] Ielasi, R., Molinas P., Ambiente e Sviluppo, 2001, EMAS quale strumento di gestione del territorio da parte di un'amministrazione comunale, Roma.

[8] Iraldo, F., 2007, Le raccomandazioni e le possibili innovazioni emergenti dallo studio Ever, IEFE, Università Bocconi, Milano.

[9] Molinas, P., Ubaldini, S., Regioni e Ambiente, 2005, Il logo EMAS: perché e come utilizzarlo per comunicare, Roma;

[10] Rocchi.A, Amodeo G.U, Jirillo R., (2007), Metodi Innovativi di gestione e certificazione ambientale, Roma, Aracne editrice.

[11] Rocchi A. Jirillo R. (2010) Impresa e ambiente: la rilevanza delle certificazioni ambientali in rapporto agli obiettivi percepiti. In Atti del congresso AISME Alghero giugno 2010.

[12] Thione, L., Sviluppi delle certificazioni ambientali in Italia, Sincert, Milano; 2004. 